transthoracic electrical impedance. Biomed. Fng., 7: 316 (1972).

6. Cotton. E. K., Cogswell, J. J., and Cropp, G. J. A.: Measurements of effective pulmonary blood flow in the normal newborn infant. Pediatrics. 47: $520(1971)$

7. Cross, K. W.: The respiratory rate and ventilation in the newborn baby. J Physiol.. 109: 459 (1949)

8 . Dahlberg, G.: Statistical Methods for Medical and Biological Students, p. 122 Allen \& Unwin and Interscience Inc., London and New York, (1940)

9. Denniston, J. C.. Maher, J. T.. Reeves: J. T., Cruz, J. C., Cymerman, A. and Grover. R. F. Measurement of cardiac output hy electrical impedance at rest and during exercise. J. Appl. Physiol., 40: 1 (1976).

10. Dinwiddie, R and Russell, $G$. The measurement of effective pulmonary capillary bleod flow in the newborn using low concentrations of nitrous oxide. Biol. Neonate. 21:83(1972)

11. Cieddes, 1.. A., and Sadler. C.: The specific resistance of blood at hesdy temperature Med. Biol. Ling., 11:336 (197.3)

12. Harley $A$ and Geenfield, J. C : Determination of cardiac output in man by means of impedance plethysmography. Acrospace Med.. 39: 248 (1968).

13. Hill, D. W., and Thompson, F. D.: The effect of hatematocrit on the resistivity of human blood at $37^{\circ} \mathrm{C}$ and $100 \mathrm{kHz}$. Med. Biol. Fng., 1.3: 187 (1975)

14. Hill, D. W., and Thompson, F. D.: The importance of blood resistivity in the measurement of cardiac output by the thoracic impedance method. Med. Biol. Eng.. 13: 187 (1975).

15. Judy W. V Langley, F, M. Mccowen, K D Stinnett, D. M., Baker. I. $E$.. and Johnson, P. C : Comparative evaluation of the thoracic impedance and isotope dilution methods for measuring cardiac output. Acrospace Med. 40): $532(1969)$

16. Kinnen. F. Cardiac output from transthoracic impedance variations. Ann

Copyright " 1977 International Pediatric Research Foundation, Inc.
V. Y Acad Sci. 170: $747(1970)$.

17. Kubicek. W. ( $i_{\text {.: }}$ Unpublished data supplied with Minnesota impedance cardiongaph.

18. Kubicek. W. G.. Karnegis, J. N., Patterson, R. P., Witsoc. D). A., and Mattson, R. H: Development and evaluation of an impedance cardiac output system. Acrospace Med., 37: 1208 (1966)

19. Lababidi, Z. Ehmke, I). A., Durnin. R. E.. Leaverton. P. F... and L.auer R. M.: Evaluation of impedance cardiac output in children. Pediatrics, 47 $870(1971)$

20. Linderholm M. H Kimbel, P. Lewis, D. H. and Dubois, A. B.: Pulmonary capillary blood fow during cardatc catheterisation. J. Appl. Physiol.. 17. $135(1962)$

21. Mohapatra, S. N., and Hill, D. W.: The changes in blood resistivity with hatmatocrit and temperature. Eur. J. Intensive (are Med., I: 153 (1976)

22. Mohapatra, S. N. Costeloe K. I... and Hill, D). W.: Blood resistivity and its implications for the calculation of cardiac output by the thoracic electrical impedance technique. Intensive Care Med., 3: 63 (1977)

23. ()rme R L Featherby F. A Rigatto, H. Cervantes, F. J.. and Brady, J. $P$ : Lffective pulmonary blood flow in a preterm infants with and without respiratory distress - A simple hedside method using $\mathrm{N}_{2} \mathrm{O}$. Pediatrics, 52 $179(1973)$.

24. Stocks, J Cisteloce K.. Winlove, C. P.. and Godfres, S. Measurement of pulmonary capillary blood flow in infants by plethysmography. J. ('lin. Invest. 59: 490 (1977)

25. Requests for reprints should be addressed to: Dr. K. Costeloe. University Department of Paediatrics, John Radeliffe Hospital. Oxford $0 \times 2$ 6HF (England)

26. Recuived for publication ()ctuber 24, 1976

27. Accepted for publication April 12, 1977

Pediat. Res. 11: 1177-1179 (1977)

Acidosis

colostrum

electrolytes human milk hyponatremia $\mathrm{pH}$

\title{
Electrolyte and pH changes in Human Milk
}

\author{
(HRISTINE: ANSELL. ANGILA MOORE, ANI) H. BARRIF:16,
}

Paediatric Research Laboratory. Charing Cross Hospital, London, England

\section{Summary}

Milk samples from 100 lactating mothers in the 10 days following delivery have been analyzed for $\mathrm{pH}$, sodium, and potassium. The sodium concentration was bigh in the first 5 days, mean $21 \pm 5 \mathrm{mmol} / \mathrm{liter}$, but fell to a mean $15 \mathrm{mmol} / \mathrm{liter}$ by the end of the first week and $12 \mathrm{mmol} /$ liter by the 10 th day. A similar downward trend was shown for potassium with an initial mean concentration of $18.5 \mathrm{mmol} /$ liter falling to 15 $\mathrm{mmol} / \mathrm{liter}$ by the 10 th day. The $\mathrm{pH}$ fluctuated widely from day to day through a range of $6.75-7.42$ with a mean $\mathrm{pH} 7.09$. Considerable variations were shown in individuals from day to day, and from the beginning to the end of feeds (Table 1 ).

The relatively high sodium concentration in the firsi few days may be an important defense mechanism against dehydration and hyponatremia during a period of relative thirst and starvation. The variation in the $\mathrm{pH}$ and electrolyte content of human milk may be expected to have some influence on the acid-base and electrolyte status of the infant.

\section{Speculation}

Hyponatremia and acidosis in neonates in the first few weeks may be attributed in part to the inappropriate $\mathrm{pH}$ and electrolyte content of artificial milk formulas based on mature human milk. The addition of sodium and base to formulas may be a desirable modification both for premature infants and for term infants in the first few weeks of life.

Renewed attention has recently been paid to the optimal mineral composition of infant feeding formulas, the assumption heing that because human milk is physiologic it is less likely to cause electrolyte or acid-base distrubances. The values usually yuoted for sodium and potassium concentrations in breast milk, and to which artificial milk formulas aspire. refer to mature milk although the different concentrations in colostrum and transitional milk have long been recognized (9). The aim of this investigation was to determine the likely intake of sodium and potassium in the first 10 days of life and to establish the normal range of $\mathrm{pH}$ of colostrum and transitional milk.

\section{MATERIALS AND METHODS}

Milk samples were taken with informed consent from a random series of 100 lactating mothers. Milk was also collected from one patient for the 10 consecutive days after delivery. Specimens were collected during the 9 AM feed by hand expression by the mother assisted by one of us (C. Ansell) using a standard technique (2). The breast was cleaned with water only and $5-\mathrm{ml}$ samples were taken into sterile universal containers approximately $1-2 \mathrm{~min}$ after starting the feed and at 
the end of the feed from both the right and left breast. The samples were transported on ice, stored at $4^{\circ}$, and analyzed the same day.

The measurements were made with a Corning EEL 165 blood gas analyzer and a Corning EEL 430 flame photometer (13) mostly on undiluted samples. Duplicate estimations were performed in both cases and a range of standards were used. Trial estimations showed that any effect of transporting the samples was negligible. The validity of flame photometry to milk was established by demonstrating linear agreement between the values obtained on serial dilutions of milk with known standards and the calculated values.

\section{RESULTS}

The sodium concentration was high in the first 5 days $(21 \pm$ $5 \mathrm{mmol} / \mathrm{liter}$ ), but fell to a mean $15 \mathrm{mmol} / \mathrm{liter}$ by the end of the first week and $12 \mathrm{mmol} / \mathrm{liter}$ by the 10 th day (Fig. 1). A similar trend was shown for potassium, with an initial mean concentration of $18.5 \mathrm{mmol} / \mathrm{liter}$, falling to $15 \mathrm{mmol} /$ liter by the 10 th day (Fig. 2). The downward trend for both these ions by analysis of variance is significant $(P<0.001)$. The $\mathrm{pH}$ of the milk varied over a wide range from day to day from values of $6.75-7.3$ with a mean pH of 7.09 (Fig. 3). Comparison of the concentrations at the beginning and the end of the feed showed a small but significant rise in sodium and $\mathrm{pH}$ in hind milk, the potassium concentration remaining constant (Table 1). Variations of potassium and $\mathrm{pH}$ from day to day and an unexpected rise of sodium were also demonstrated in an individual mother (Fig. 4).

\section{DISCUSSION}

The changing secretions of the mammary gland from quiescence to active lactation has long been recognized (9). The

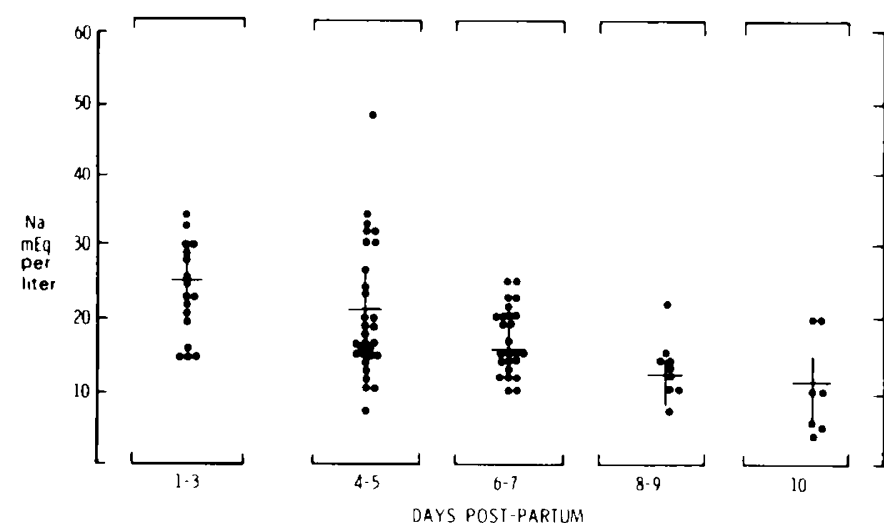

Fig. 1. Sodium concentrations in human breast milk during the puerperium.

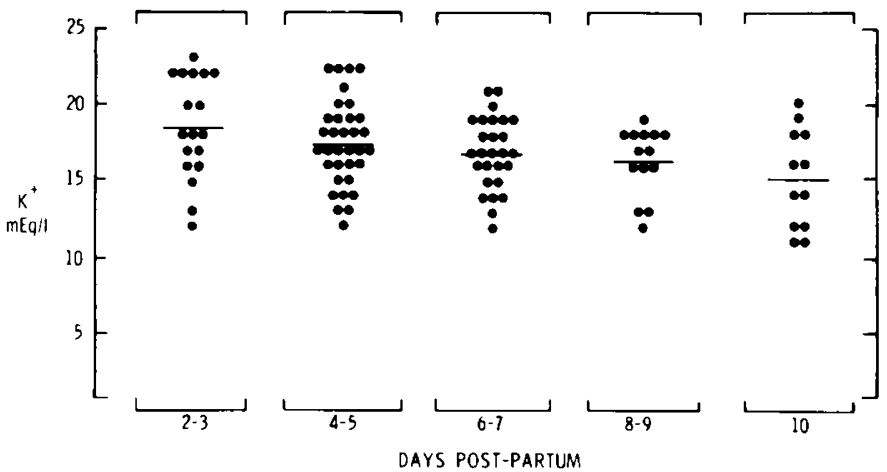

Fig. 2. Potassium concentration in human breast milk during the puerperium.

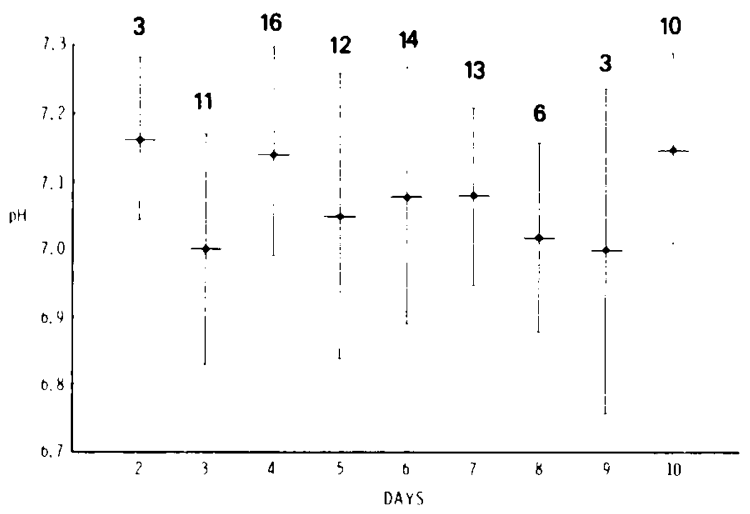

Fig. 3. Changes in pH of breast milk for days $1-10$. Numbers refer to samples analyzed. Horizontal lines $=$ mean; vertical lines $=1 \mathrm{SD}$.

Table 1. pH, sodium and potassium concentrations from beginning to end of feed'

$\begin{array}{cccc}\text { Feed } & \mathrm{Na}, \mathrm{mEq} / \text { liter } & \mathrm{K}, \mathrm{mEq} / \mathrm{liter} & \mathrm{pH} \\ \text { Fore milk } & 19.1 & 17.3 & 7.06 \\ & \pm 7.9 & \pm 2.9 & \pm 0.16 \\ \text { Hind milk } & 20.4 & 17.2 & 7.11 \\ & \pm 8.5 & \pm 2.9 & \pm 0.17 \\ P \text { value } & <0.05 & \mathrm{NS} & 0.001\end{array}$

1 Values are for 100 samples of fore and hind milk; \pm values $=1$ SD.

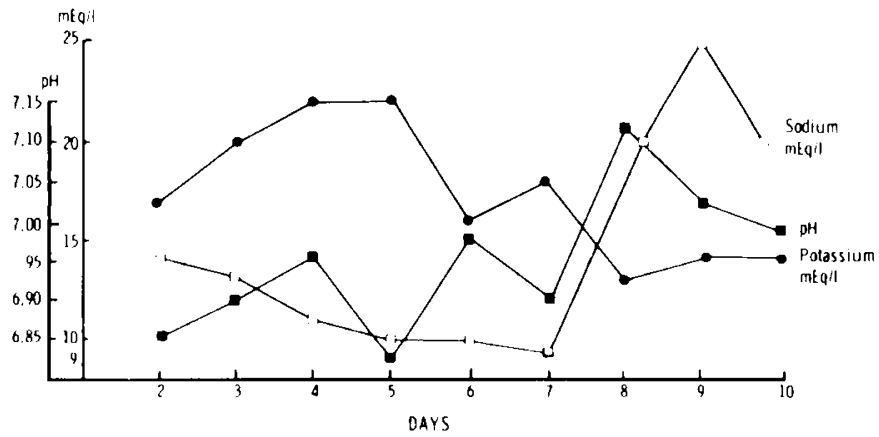

Fig. 4. Changes in concentration of sodium, potassium, and $\mathrm{pH}$ in patient $T D$ for days $1-10$.

marked fall in both sodium and potassium concentrations is in agreement with previous data (10). Gunther et al. (3) found a downward trend for sodium of from $23-80 \mathrm{mmol} / \mathrm{liter}$ in colostrum to $11-23 \mathrm{mmol} /$ liter in transitional and finally to a mean of $15 \mathrm{mmol} / \mathrm{liter}$ in mature milk. The secretion of potassium in human milk is not so clearly documented. Some workers (3, 11) reported a gradual rise of from $10-19 \mathrm{mmol} / \mathrm{liter}$ in colostrum to 15-20 $\mathrm{mmol} / \mathrm{liter}$ in transitional milk whereas others. as we did, found a gradual downward trend with the establishment of mature milk.

The relatively high potassium and low sodium concentrations in mature milk suggest its derivation from an intracellular source rather than from leakage of extracellular fluid and alveolar cells. It has been shown that although a sodium pump appears to be present at the basal and lateral surface of the cell. it is not present at the apical membrane, where ions may diffuse across their respective concentration gradients (8).

Colostrum is formed and stored in the mammary gland in the late pregnancy and clearly differs in ionic composition from mature milk. Milk secreted before delivery is not removed and the pressure in the gland rises until a partial equilibrium is established between secreted milk and extracellular fluid (6). Testing the hypothesis of substances passing between, rather than through, cells, it has been shown that even a relatively 
small leak in the epithelium separating extracellular fluid from milk has a major effect on milk composition (7).

It is known that the amount of fat in the milk rises continuously during the course of the feed (5), but this is unlikely to account for the differences in the concentration of sodium.

There is a relative scarcity of data on the $\mathrm{pH}$ of colostrum and transitonal milk, but a mean $\mathrm{pH}$ of 7.29 has been reported for mature milk (4). Although considerable variation was found in the $\mathrm{pH}$ of human milk. little is known about its control. That it does not necessarily reflect the maternal acid-base status is suggested by studies in lactation in goats in whom milk $\mathrm{pH}$ of 6.32 is significantly lower than that of blood. whereas milk $\mathrm{pCO}_{2}$ is almost identical to that of mammary venous blood (8). Dehydration and abnormal food intake, especially after delivery. may result in a degree of ketoacidosis, with consequent changes in the composition of the milk. Phosphate, citrate, and proteins are the main buffers in mature milk. Apart from chemical changes milk $\mathrm{pH}$ can be affected by loss of $\mathrm{CO}_{2}$ in sampling and storage and for this reason every effort was made to analyze the samples as soon as possible.

\section{CONCLUSION}

Considerable differences in the composition of colostrum and early milk have been shown to occur between different mothers and also in the same mother on different days. The variation in the composition of human milk, both with respect to individual mothers and to the state of lactation, may influence the electrolyte and acid-base state of the infant. The relatively high sodium concentration in the first few days may be an important defense mechanism against dehydration and hyponatremia during a period of relative thirst and starvation. With the current emphasis on the adjustment of sodium in modified milk formulas it may be argued that the sodium intake in bottle-fed babies in the first 10 days is too low, and in very low hirth weight babies. severe hyponatremia and hypokalemia (plasma $\mathrm{K}^{+}<5.5 \mathrm{mEq} /$ liter) have been reported in infants fed with these solute formulas (1). The $\mathrm{pH}$ of milk has been unjustifiably neglected bottle-fed infants being more likely to develop a metabolic acidosis than those who are breastfed (12). An adjustment with respect to sodium and base in milk formulas for infant feeding in the first few days after birth may he desirable.

\section{RIFFERENCIS AND N(ITES}

1. Day. G. M. Radde, I. (C., Balfe, J. W., and ('hance (i. W.: Relectrolyte abnormalities in very low birthweight infants. Pediat. Res., 10:522 (1976) 2. Gunther, M.: Infant Feeding. (Penguin Books, Baltimore, 1971)

3. Gunther. M., Hawkins. D. F.. and Whyley. (;. A .: Some observations on the sodium and potassium content of human milk. J. Obstet. (iynaceol. Brit. Commonw. 72: 69 $(1965)$.

4. Harrison, V.C., and Peat G.: Significance of milk pH in newborn infants. Br. Med. J.. (ii) 515 (1972)

5. Hytten. F. F.: (Clinical and chemical studies in human lactation. Br. Med. J (i): $175(1954)$

6. I.inzell, J. L.: Physiology of the mammary glands. Physiol. Rev.. 39: 5.34 (1459).

7. I.inzell, J. I... and Peaker, M.: Changes in colostrum composition and in the permeability of the mammary epithelium at about the time of parturition in the goat. J. Physiol., 243: 129(1974).

8. Linzell. J. L., and Peaker, M.: The distribution of carbon dioxide, carbonic acid and bicarbonate between blood and milk in the goat. J. Physiol.. 244: $771(1975)$.

9. Macy, 1. G.: Composition of human colostrum and milk. Amer. J. Dis (hild. 78: $589(1949)$.

10. Macy, I. G., and Kelly, H. J.: The mammary gland and its secretion. In: S. K. Kon and A. T. Cowic: Milk. Vol. II (Academic Press. New York. $1961)$.

11. Terheggen, H. G.: Uher den Calcium, Kalium, und Natriumgehalt der Freuenmilch. Z. Kinderheilk. 92:193 (1965)

12. Moore, A.. Ansell. C... and Barrie, H.: Metabolic acidosis and infant feeding Br. Med. J., (i): 129 (1977).

13. Corning Led.. Halstead. Essex. C(19) 2DX. England.

14. We thank Dr. Macrac for help with the statistics and the staff and mothers in the maternity unit at the West London Hospital and St. Teresa's Hospital for their cooperation.

15. This work was supported by grants from the Clinical Research Committee of Charing Cross Hospital. Cow \& Gate Babyfoods L.d., and an anonymous donor.

16. Requests for reprints should be addressed to: H. Barrie, M.D., FRCP. Department of Paediatrics. Charing Cross Hospital. Fulham Palace Road. Londor. W6 8RF (England).

17. Received for putlication December 16.1976.

18. Accepted for publication April 12. 1977. 